\title{
PENGAWETAN IKAN TONGKOL (Euthynnus affinis) MENGGUNAKAN SARI DAUN JAMBU BIJI (Psidium guajava) SELAMA PENYIMPANAN SUHU RUANG
}

\author{
Mita Pratiwi Nihali; Rieny Sulistijowati ${ }^{1}$; Nikmawatisusanti Yusuf ${ }^{1}$ \\ 1 Jurusan Teknologi Hasil Perikanan, Fakultas Perikanan dan Ilmu Kelautan, Universitas Negeri Gorontalo, \\ J..Jenderal Sudirman No.06, Kota Gorontalo 96128, Gorontalo, Indonesia \\ "Korespondensi: mhita.pratiwi86@gmail.com \\ (Diterima 23-02-2020; Direvisi 26-04-2020; Dipublikasi 16-06-2020)
}

\begin{abstract}
ABSTRAK
Penelitian ini bertujuan untuk mengetahui mutu ikan tongkol (Euthynnus Affinis) yang diawetkan dengan sari daun jambu biji selama penyimpanan. Perlakuan pada penelitian ini adalah lama penyimpanan ikan tongkol dengan sari daun jambu biji 50\% dengan taraf waktu 15 jam, 18 jam dan 21 jam. Penelitian ini dirancang menggunakan metode Multirater Rasch Model untuk mendapatkan data hasil mutu organoleptik dan dianalisis dengan Minifac. Data hasil mikrobiologi Total Plate Count (TPC) diperoleh melalui Rancangan Acak Lengkap (RAL) dan dianalis dengan Compare Means OneWay ANOVA. Hasil berdasarkan analisis rasch model menunjukkan bahwa penyimpanan ikan tongkol 15 jam merupakan perlakuan terbaik pada parameter kenampakan mata: bola mata rata; Insang: merah tua cemerlang dengan sedikit lendir; Daging: jaringan kuat, Tekstur: agak lunak agak elastic , dan pada peyimpanan 18 jam terbaik pada parameter bau yaitu segar spesifik ikan. Nilai mutu organoleptik lama penyimpanan 15 jam dan 18 jam memenuhi standar SNI 2729-2013. Hasil analisis mikrobiologi memberikan pengaruh nyata pada total bakteri pada penyimpanan $15 \mathrm{jam} \log 3,20 \mathrm{Cfu} / \mathrm{g}$, penyimpanan 18 jam log 5,22 Cfu/g, penyimpanan 21 jam log 5,67 CFU/g dimana SNI $5 \times 10^{5}$.
\end{abstract}

Kata Kunci : ; Ikan Tongkol; Organoleptik; Pengawetan, Sari Daun Jambu; TPC.

\section{Preservation of Tuna Fish (Euthynnus affinis) using Guava Leaf Extract (Psidium guajava) During Room Temperature Storage}

\section{ABSTRACT}

This study aims to determine the quality of tuna (Euthynnus Affinis) preserved with guava leaf extract during storage. The treatment in this study was the storage time of tuna with $50 \%$ guava leaf extract with time levels of 15,18 , and 21 hours. This research was designed using the Multirater Rasch Model method to obtain organoleptic quality data and analyzed with Minifac. Data from the Microbiology Total Plate Count (TPC) was obtained through a Completely Randomized Design (CRD) and analyzed with Compare Means One-Way ANOVA. The results based on the analysis of the Rasch model should be including that 15 hour tuna storage is the best treatment should be including eye appearance: (flat eyeball), Gills (bright red with a little mucus), Meat (strong tissue), texture (rather soft rather elastic), and at 18 hours storage is best on the odor parameter that is fresh fish specific. Organoleptic quality value of 15 hours and 18 hours storage time correaponding SNI 2729-2013 standards. The results of microbiological analysis had a significant effect on total bacteria in 15 hours (log $3.20 \mathrm{Cfu} / \mathrm{g}$ storage), 18 hours (log $5.22 \mathrm{Cfu} / \mathrm{g}$ storage), 21 hours (log $5.67 \mathrm{CFU} / \mathrm{g}$ storage) where SNI $5 \times 10^{5}$.

Keywords: Euthynnus affinis; Organoleptic; Psidium guajava; Preservation; Total Plate Count 


\section{PENDAHULUAN}

Data produksi perikanan laut di Provinsi Gorontalo adalah 139.042 ton dan dari total ini sebesar 137.299 ton ikan dipasarkan dalam bentuk segar, salah satunya adalah ikan tongkol (Euthynnus affinisi) yang produksinya mencapai 16.686 ton. Di Provinsi Gorontalo, potensi ikan tongkol pada tahun 2011 mencapai 7.609 ton (DKP Gorontalo, 2011).

Ikan tongkol hanya dapat bertahan sebelum 15 jam pada penyimpanan suhu ruang. Berdasarkan hasil penelitian Ishak $d k k$. (2015), ikan tongkol yang disimpan pada suhu ruang selama 15 jam memiliki kandungan bakteri sebanyak $5.75 \times 10^{5}$ koloni/g. Angka ini sudah melewati batas Standarisasi Nasional Indonesia (SNI). Ikan segar yaitu $5 \times 10^{5}$ koloni/g. Kondisi tersebut dapat merugikan karena dengan demikian banyak ikan tidak dapat dimanfaatkan dan terpaksa dibuang, terutama saat produksi ikan melimpah. Oleh karena itu dibutuhkan proses pengawetan yang bertujuan menghambat atau mencegah terjadinya kerusakan, mempertahankan mutu, menghindari terjadinya keracunan, dan mempermudah penanganan dan penyimpanan. Untuk menghindari pengawetan menggunakan bahan kimia yang berdampak buruk bagi kesehatan, dibutuhkan pengawet yang bersumber dari bahan alami.

Penelitian mengenai pengawet bahan alami yang diaplikasikan pada ikan tongkol dan disimpan pada suhu ruang yang telah dilakukan; Ahmad (2014), ikan tongkol yang direndam ekstrak jeruk nipis dan dapat bertahan hingga 12 jam penyimpanan, karena kandungan bakterinya masih berada dibawah standar yaitu $5.4 \times 10^{3}$ koloni/g. Sidiki (2015), ikan tongkol yang dilumuri bawang putih dapat bertahan hingga 24 jam penyimpanan, kandungan bakterinya juga masih belum melewati batas standar yaitu $2 \times 10^{5}$ koloni/g, Ishak $d k k$. (2015), ikan tongkol yang direndam filtrat asam laktat kulit nanas dapat bertahan hingga 20 jam dengan kandungan bakteri $2.6 \times 10^{4} \mathrm{koloni} / \mathrm{g}$.

Mengingat akan bahaya penggunaan pengawet kimia, perlu usaha untuk menemukan pengawet dari bahan yang alami. Jambu biji adalah suatu tanaman buah jenis perdu, dalam bahasa inggris disebut (Psidium guajava). Manfaat ekstrak menurut para ahli mikrobiologi di Bangladesh, jambu biji melindungi dari bakteri mikroba pathogen, seperti Staphylococcus aureus (Ide, 2011).

Penelitian tentang daun jambu biji (Psidium guajava Linn.) sebagai antibakteri sebelumnya sudah dilakukan, antara lain penelitian yang dilakukan oleh Darsono $d k k$, (2003) terhadap bakteri Staphylococcus aureus, dan penelitian terhadap Salmonella typhymurium oleh (Azizah, 2004). Penelitian daun biji (Psidium guajava Linn.) terhadap bakteri penyebab karies yaitu Streptococcus mutans juga sudah pernah dilakukan dengan konsentrasi $1,5 \%, 2 \%, 2,5 \%, 3 \%$, dan $3,5 \%$. 
Berdasarkan penelitian tersebut didapatkan nilai Kadar Hambat Minimum (KHM) ekstrak daun jambu biji (Psidium guajava Linn.) terhadap bakteri Sterpcoccus mutans adalah $2 \%$ dan nilai Kadar Bunuh Minimum (KBM) adakah 3,5\% (Hermawan dkk, 2012).

Menurut Danarsi dan Noer (2016), jumlah dan jenis mikroorganisme dapat menentukan mutu mikrobiologis dalam bahan pangan. Hal ini lebih lanjut akan menentukan ketahanan simpan dari produk tersebut jika ditinjau dari kerusakan oleh mikroorganisme selama penyimpanan. Oleh sebab itu, penggunaan sari daun jambu biji perlu dilakukan karena senyawa yang terkandung memiliki potensi untuk memperlambat kemunduran mutu ikan atau produk hasil perikanan.

Penelitian terkait mutu organoleptik dan mutu mikrobiologis ikan laut khususnya pada ikan tongkol (Eutynus affinis) selama penyimpanan belum dilaporkan, sehingga perlu dilakukan. Penelitian ini bertujuan mengetahui mutu organoleptik dan mutu mikrobiologis ikan laut khususnya pada ikan tongkol (Eutynus affinis) selama penyimpanan.

\section{METODE PENELITIAN}

\section{Waktu dan Lokasi Penelitian}

Penelitian ini dilaksanakan pada bulan Agustus 2018 sampai Desember 2018. Tempat pengujian mikrobiologi dilakukan di Balai Pembinaan Tempat Pengujian Mutu Pengujian Mutu Hasil Perikanan (BPPMHP) Kota
Gorontalo sedangkan pengujian mutu organoleptik dilakukan di Fakultas Perikanan dan IImu Kelautan Universitas Negeri Gorontalo.

\section{Alat dan Bahan}

Alat yang akan digunakan adalah cool box, blender (miyako $\mathrm{CH}-501$, China) timbangan digital (KS HL-4350, China), dan lembar score sheet ikan segar, alat-alat gelas (Pyrex, Japan), magnetic stirrer, hot plate (Favorit HP0707V2), autoclave, label, cawan (Pyrex, Japan), timbangan analitik, stomacher, waterbath (WSB 18L, Korea South), coloni counter, inkubator, oven, mikro pipet (Gilson, Swiss), kertas aluminiumfoil, laminari air flow, dan kapas.

Bahan baku yang digunakan adalah ikan tongkol segar, es batu, sari daun jambu biji. Ukuran berat ikan tongkol yang digunakan dalam penelitian adalah \pm 250 gr/ekor ( 3 ekor atau sama dengan $750 \mathrm{gr}$ )

\section{Prosedur penelitian}

\section{Tahap Pembuatan Sari Daun Jambu Biji}

Pembuatan sari daun jambu biji diawali dengan pemanenan daun jambu biji yang dilaksanakan pada pagi hari. Daun jambu biji yang diperlukan untuk penelitian sebanyak 100 gr. Daun jambu biji yang telah telah disediakan dibersihkan dengan air lalu diblender hingga halus kemudian dicampurkan kedalam $100 \mathrm{ml}$ air. Dengan perbandingan 1:1 kemudian dihomogenkan menggunakan blender sehingga diperoleh sari daun jambu 
yang siap digunakan sebagai bahan pengawet ikan tongkol.

\section{Tahap Perlakuan}

Prosedur penelitian utama dilakukan dengan langkah-langkah sebagai berikut :

Sampel ikan tongkol segar yang dibeli dari TPI kota Gorontalo sekitar pukul 06.00 pagi, dimasukkan dalam coolbox yang diberi es curah, dengan perbandigan es dengan ikan 2:1. Ikan tongkol kemudian ditimbang. Hasil penimbangan berat ikan \pm 250 g/ekor, selanjutnya ikan tongkol dilumuri sari daun jambu dengan konstrasi 50\%, kemudian disimpan pada suhu ruang. Perlakuan lama penyimpanan 15 jam, 18 jam dan 21 jam dan dilakukan pengujian total jumlah bakteri dan organoleptik.

Metode yang di gunakan pada penelitian ini adalah Metode eksperimen dengan menggunakan Rancangan Acak Lengkap (RAL).

\section{HASIL DAN PEMBAHASAN}

\section{Hasil Pengujian Mutu Organoleptik Ikan Tongkol Segar}

Pengujian organoleptik ikan tongkol yang dilumuri sari daun jambu biji dengan perlakuan, 15 jam, 18 jam dan 21 jam, menggunakan pengujian mutu organoleptik dengan 25 orang panelis. Hasil pengujian mutu organoleptik meliputi kenampakan mata, insang, daging, bau, dan tekstur.

http://ejurnal.ung.ac.id/index.php/jpj/issue/arch

\section{Kenampakan Mata}

Gambar hasil analisis probability kenampakan ikan dapat dilihat pada Gambar 1

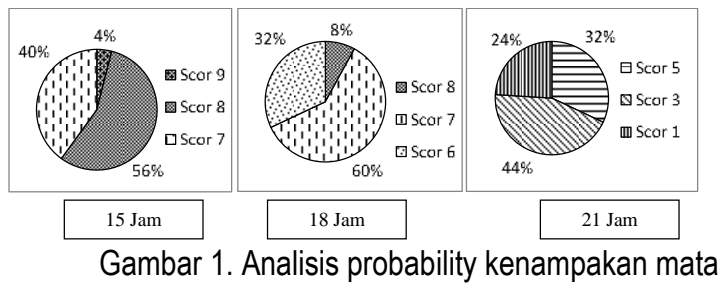

Hasil uji RASCH Model menunjukkan bahwa nilai mutu organoleptik terhadap mata ikan tongkol segar yang dilumuri dengan sari daun jambu biji yang disimpan pada lama penyimpanan yang berbeda berada pada interval 1-9. Nilai tertinggi pada lama penyimpanan 15 jam skor nilai 8 , dengan nilai $56 \%$ dengan kriteria Bola mata rata, kornea agak keruh, pupil agak keabu-abuan, agak mengkilap spesifik jenis ikan. Hal ini dibuktikan dengan hasil analisis probability bahwa nilai mutu organoleptik terhadap kenampakan ikan tongkol.

Lama penyimpanan 15 jam dan 18 jam mata ikan masih memenuhi syarat (2346-2006), hal ini karena adanya larutan sari daun jambu biji yang diduga menghambat proses kemunduran mutu mata ikan akibat aktivitas mikroba. Seiring dengan semakin lama penyimpanan yaitu 21 jam mata ikan mulai mengalami penurunan mutu hal ini berkaitan erat dengan senyawa antibakteri pada ikan tongkol. Menurut Agati, dkk (2007) dalam Herawati (2011) permeabilitas membran sel pada mata ikan terganggu akibat adanya 
senyawa fenol. Senyawa fenol yang terkandung dalam daun jambu biji mempengaruhi nilai organoleptik penampakan mata, sehingga sangat cepat terjadi perubahan pada mata ikan.

\section{Insang}

Hasil uji RASCH Model menunjukkan bahwa nilai mutu organoleptik terhadap insang ikan tongkol segar yang dilumuri dengan sari daun jambu biji yang disimpan pada lama penyimpanan yang berbeda berada pada interval 1 - 9. Nilai tertinggi terdapat pada lama penyimpanan 15 jam, scor nilai 8 dengan persentasi nilai $44 \%$ dengan kriteria; warna insang merah tua, kurang cemerlang dengan sedikit lendir transparan. Hasil analisis probability insang dapat dilihat pada Gambar 2.

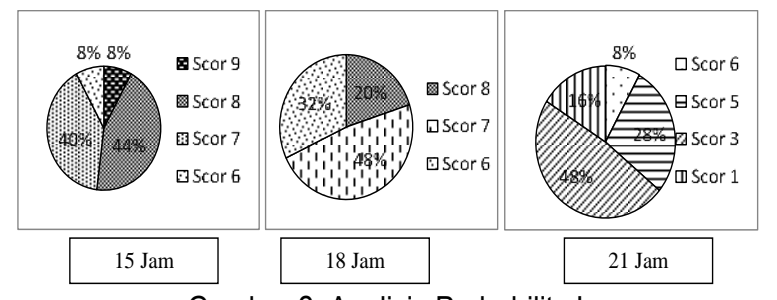

Gambar 2. Analisis Probability Insang

Lama penyimpanan 15 jam dan 18 jam insang ikan tongkol dapat dipertahankan dengan menggunakan sari daun jambu biji. Antimikroba yang terkandung dalam sari jambu biji dapat digunakan sebagai pencegah aktivitas bakteri penyebab penurunan mutu ikan. Namun seiring lama penyimpanan yaitu penyimpanan 21 jam nilai organoleptik insang semakin menurun, kemungkinan dipengaruhi oleh adanya bakteri. Hal ini sesuai dengan hasil penelitian Mile (2008), bahwa perubahan warna insang dapat dipengaruhi oleh bakteri diantaranya bakteri adalah bakteri Aeromonas dan Vibrio. Menurut Fujaya (2004) penurunan mutu yang cepat pada kenampakan insang tidak terlepas dari kinerja insang yang memfilter oksigen dalam air saat respirasi sehingga insang menjadi tempat terakumulasinya mikroba.

\section{Daging}

Hasil uji RASCH Model menunjukkan bahwa nilai mutu organoleptik terhadap daging ikan tongkol segar yang dilumuri dengan sari daun jambu biji yang disimpan pada lama penyimpanan yang berbeda berada pada interval $1-9$. Nilai tertinggi terdapat pada lama penyimpanan 15 jam skor nilai 8 dengan presentasi nilai $48 \%$ dengan kriteria sayatan daging cemerlang spesifik jenis, jaringan daging sangat kuat. Hasil analsiis probability daging dapat di lihat pada Gambar 3.

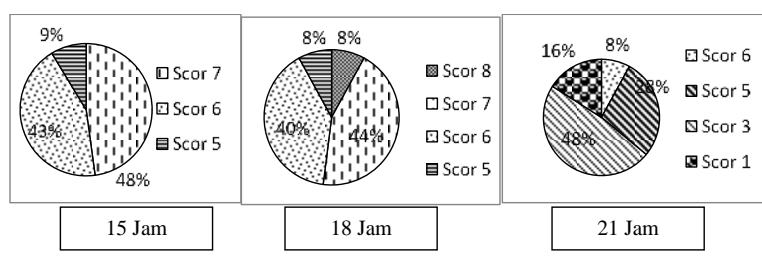

Gambar 3. Analisis Probability sampel ikan tongkol pada daging

Lama penyimpanan 15 jam dan 18 jam daging ikan tongkol dapat dipertahankan karenanya adanya perlakuan sari daun jambu biji. Purwiyatno (2006) menyatakan bahwa komponen aktif tanin dalam daun jambu biji mampu menghambat pertumbuhan 
mikroorganisme, serta penyera racun dan dapat mengumpulkan protein.

Namun seiring dengan lama penyimpanan nilai organoleptik daging semakin menurun, hal ini dipengaruhi oleh adanya beberapa bakteri. Menurut Afrianto dan Liviawaty (2011), kenampakan daging, terutama pada warna sayatan dipengaruhi oleh reaksi oksidasi antara oksigen dengan komponen lemak pada ikan kusam. Daging ikan hampir seluruhnya terdiri dari daging bergaris melintang yang dibentuk oleh serabut-serabut daging. Atribut sensorik daging berkaitan pula dengan dinding perut ikan, pada lama pnyimpanan 21 jam dinding perut ikan sudah mulai lembek dibandingkan lama penyimpanan 15 jam dan 18 jam. Pemerahan di sepanjang tulang belakang, pemerahan pada tulang belakang yang lebih tampak pada lama penyimpanan 21 jam karena rusaknya jaringan dinding-dinding sel dari pembuluh darah maupun daging ikan telah rusak akibat aktivitas mikroba. Bagian perut merupakan salah satu tempat mikroba banyak bertumbuh selain pada insang dan kulit (Junianto 2003).

\section{Bau}

Hasil uji RASCH Model menunjukkan bahwa nilai mutu organoleptik terhadap bau ikan tongkol segar yang dilumuri dengan daun jambu biji yang disimpan pada lama penyimpanan yang berbeda berada pada interval $1-9$. Nilai paling tertinggi terdapat pada lama penyimpanan 18 jam, skor nilai 8 dengan persentasi nilai $60 \%$ dengan kriteria; segar, spesifik jenis. Hasil analisis probability dapat dilihat pada Gambar 4.

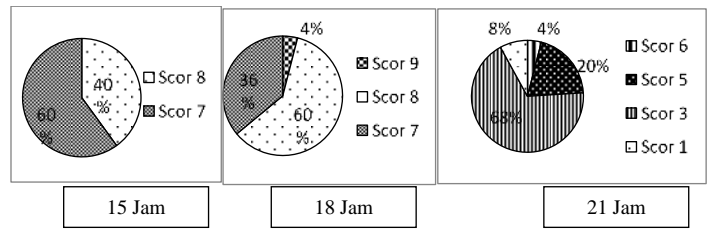

Gambar 4. Analisis Probability ikan tongkol pada bau

Lama penyimpanan 15 jam dan 18 jam bau ikan tongkol dapat dipertahankan karenanya adanya perlakuan sari daun jambu biji. Hal ini berkaitan erat dengan aktivitas bakteri pada ikan tongkol serta sari daun jambu biji yang digunakan. Daun jambu biji memberikan bau yang nyata pada ikan, hal ini disebabkan karena senyawa minyak atsiri pada daun jambu biji termasuk golongan senyawa yang volatile.

Penurunan mutu organoleptik bau ikan tongkol seiring dengan penurunan mutu mikrobiologis yaitu berdasarkan jumlah bakteri TPC. Hasil analisis organoleptik bau ikan maupun hasil pengujian TPC ikan menunjukkan hasil yang saling berkaitan. Semakin tinggi jumlah bakteri pada ikan tongkol semakin rendah nilai organoleptik bau, begitu pula sebaliknya. Hal ini disebabkan karena bau yang timbul dari ikan, merupakan bau yang timbul akibat kerusakan komponen-komponen ikan. Kerusakan tersebut disebabkan oleh aktivitas dan perombakan yang dilakukan bakteri. 


\section{Tekstur}

Hasil uji RASCH Model menunjukkan bahwa nilai mutu organoleptik terhadap tekstur ikan tongkol segar dengan perlakuan sari daun jambu biji disimpan pada lama penyimpanan berbeda berada pada interval $1-9$. Nilai tertnggi terdapat pada lama penyimpanan 15 jam, skor nilai 8 dengan persentasi nilai $32 \%$ dengan kriteria; padat kompak elastik. Hasil analisis probability tekstur dapat dilihat pada Gambar 5.

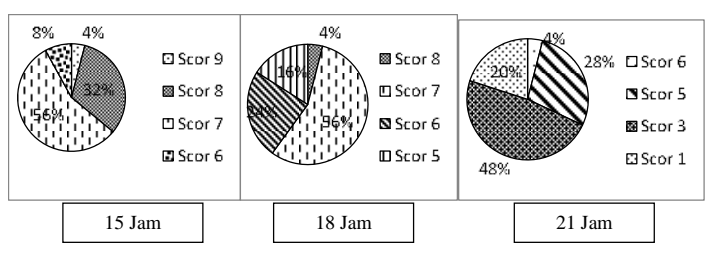

Gambar 5. Analisis Probability lkan Tongkol Pada Parameter Tekstur

Lama penyimpanan 15 jam tekstur ikan tongkol dapat dipertahankan dan masih memenuhi SNI (01-2346-2006), sedangkan semakin lama penyimpanan yaitu 18 jam dan 21 jam terjadi penurunan mutu tekstur. Penurunan mutu tekstur tersebut dipicu oleh adanya aktivitas enzim mikroba yang mengubah daging ikan menjadi lebih lunak, tekstur pula berkaitan dengan daya ikat air yang berhubungan pula dengan denaturasi protein ikan. Berhimpon (1993) menyatakan bahwa perubahan tekstur daging menjadi lebih lunak akibat perombakan pada jaringan otot daging oleh proses enzimatis dan keluarnya lendir permukaan kulit oleh mikroba sehingga menandakan kemunduran mutu.

\section{Hasil Pengujian Mikrobiologis Total Plate Count (TPC) Ikan Tongkol Segar}

Pengujian TPC untuk mengetahui efektifitas daun jambu biji sebagai antibakteri, hasil pengujian dapat dilihat pada Gambar 6 .

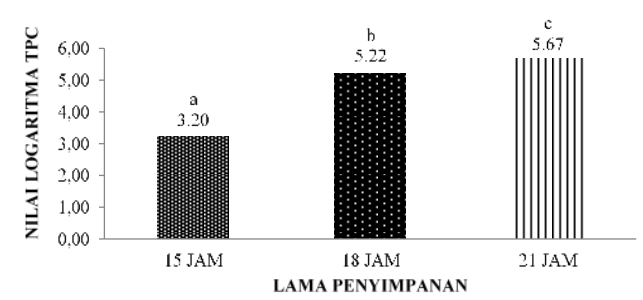

Gambar 6. Histogram nilai TPC ikan tongkol pada lama penyimpanan yang berbeda. *Angka-angka yang diikuti huruf berbeda signifikan berbeda nyata pada taraf uji $5 \%$

Berdasarkan histogram pada Gambar 6, terjadi kenaikan jumlah mikroba pada lama penyimpanan yang berbeda. Hasil pengujian diperoleh bahwa nilai log TPC tertinggi pada sampel dengan lama penyimpanan 21 jam yaitu sebanyak 5,67 CFU/gr, sedangkan terendah pada lama penyimpanan 15 jam sebanyak $3,20 \mathrm{CFU} / \mathrm{gr}$.

Batas maksimal nilai TPC pada ikan segar oleh badan standarisasi nasional adalah maksimal $5 \times 10^{5}$ koloni/gr (nilai log maksimal 5,7 CFU/g). Secara keseluruhan hasil pengujian nilai TPC pada semua konsentrasi perlakuan masih memenuhi syarat SNI karena nilai TPC masing-masing masih dibawah batas maksimal TPC (BSN, 2013). Namun pada perlakuan 21 jam pertumbuhan bakteri semakin banyak atau tidak dihambat oleh senyawa aktif seperti senyawa fenolik sehingga masih 
memungkinkan untuk mengalami kemunduran mutu mikrobiologis yang lebih cepat.

Rendahnya jumlah bakteri pada perlakuan 15 jam menandakan bahwa daun jambu biji dapat menekan pertumbuhan bakteri karena memiliki senyawa antibakteri diantaranya flavonoid, polifenol, karoten, saponin dan tanin. Menurut BPOM (2004) senyawa yang mendominasi pada daun jambu biji putih ialah golongan polifenol yaitu flavonoid sebesar $(>1,4 \%)$ dan tanin.

Semakin lama penyimpanan yaitu pada lama penyimpanan 18 jam dan 21 jam jumlah bakteri semakin meningkat. Hal ini diduga senyawa jambu antibakteri pada jambu biji tidak efektif lagi. Namun bertambahnya jumlah bakteri pada ikan masih memenuhi standar TPC pada ikan segar yaitu maksimal $5 \times 10^{5}$ koloni/gr (nilai log maksimal 5,7 CFU/g). Secara keseluruhan hasil pengujian nilai TPC pada semua konsentrasi perlakuan masih memenuhi syarat SNI karena nilai TPC masing-masing masih dibawah batas maksimal TPC (BSN, 2013).

\section{SIMPULAN}

Berdasarkan hasil penelitian dapat disimpulkan bahwa pada ikan tongkol segar dengan perlakuan sari daun jambu biji 50\% dengan lama penyimpanan 15 jam merupakan perlakuan terbaik dengan kriterian kenampakan mata; bola mata rata, insang; merah tua cemerlang dengan sedikit lendir, daging; jaringan kuat, tekstur; agak lunak agak elastik, sedangkan lama peyimpanan 18 jam terbaik pada parameter bau yaitu segar spesifik ikan. Nilai mutu organoleptik lama penyimpanan 15 jam dan 18 jam memenuhi standar SNI 27292013. Hasil analisis mikrobiologi memberikan pengaruh nyata pada total bakteri pada penyimpanan 15 jam log 3,20 Cfu/gr, penyimpanan 18 jam $\log 5,22 \mathrm{Cfu} / \mathrm{g}$, penyimpanan 21 jam log 5,67 CFU/gr dengan SNI $5 \times 10^{5}$.

\section{DAFTAR PUSTAKA}

Ahmad, A. 2014. Pemanfaatan Ekstrak Jeruk Nipis (C. Aurantifolla swingle) Terhadap Mutu Ikan Tongkol Segar [Skripsi]. Jurusan Teknologi Hasil Perikanan. Fakultas Perikanan dan IImu Kelautan. UNG. Gorontalo.

Azizah, A. 2004. Sensitivitas Salmonella Typhimurium Terhadap Ekstrak Daun Jambu Biji Psidium Guajava. Bioscientiae. Banjarmasin.

Badan Standarisasi Nasional (BSN). 2006a. SNI 01-2332-3-2006, Cara Uji Mikrobiologi Bagian 3: penentuan angka lempeng total (ALT) pada Produk Perikanan. Badan Standarisasi Nasional. Jakarta.

Badan Standardisasi Nasional (BSN). 2009. Batas Maksimum Cemaran Mikroba dalam Pangan. SNI 7388 : 2009. IC S 67.220.20.

Danarsi, C.S., Noer, E.R. 2016. Pengaruh Lama Penyimpanan Terhadap Mutu Mikrobiologi Makanan Pendamping Air Susu Ibu (MP-ASI) Bubur Instan Dengan Subtitusi Tepung lkan Gabus Dan Tepung Labu Kuning. Journal of Nutrition College. 5(2): 58-63.

Darsono, Lanawati, F., Artemisia, S.D. 2003. Efektivitas Antimikroba Ekstrak Daun 
Jambu Biji dari Beberapa Kultivar Terhadap Staphylococcus aureus ATCC 25923 dengan Hole Plate Diffusion Method. Berk Penel Hayati. Surabaya. Hal: 49-51.

Fujaya, Y. 2004. Fisiologi Ikan Dasar Pengebangan Teknik Perikanan. Cetakan Pertama. Rineka Putra. Jakarta

Hermawan, Rian, Adi, P., Noorhamdani. 2012. Uji Efektivitas Ekstrak Daun Jambu Biji Sebagai Antimikroba Terhadap bakteri Penyebab Karies Streptococcus mutans secara in Vitro. Universitas Brawijaya. Malang.

Ishak, R.A., Sulistijowati, R., Dali, F.A. 2015. Analisis Total Bakteri Kontaminasi dan Nilai Organoleptik Ikan Tongkol Segar yang Diawetkan dengan Filter Asam Laktat Kulit Nanas pada Penyimpanan Suhu Kamar. Nike: Jurnal IImiah Perikanan dan Kelautan. 3(3): 122-124

Junianto. 2003. Teknik Penanganan Ikan. Jakarta: Penebar Swadaya.

Mile, L. 2008. Penggunaan es air kelapa terhadap daya awet ikan layang (Decapterus macrosoma) dan Ikan Kakap Merah (Lutjanus Sp). Tesis. IImu Perairan. Program Pascasarjana. Universitas Sam Ratulangi. Manado.

Sidiki, V.T. 2015. Pengaruh Penggunaan Bawang Putih (Allium sativum $L$ ) terhadap Mutu Organoleptik, Koloni Bakteri dan Histamin Pada Ikan Tongkol (Euthynus Affinis) selama penyimpanan suhu Ruang. Skripsi. Fakultas Perikanan dan IImu Kelautan. Universitas negeri Gorontalo.

SNI.2006. SNI No.01-2729. 1-2006. Ikan Segar- Bagian 1: Spesifikasi. 